\title{
CLINICAL OBSERVATIONS OF UNRESPONSIVE MUCOSAL LEISHMANIASIS
}

\author{
PHILIP D. MARSDEN,* HÉLIO A. LESSA, MARIA R. F. OLIVEIRA, GUSTAVO A. SIERRA ROMERO, \\ JAQUELINE G. MAROTTI, RAIMUNDA N. R. SAMPAIO, ALDINA BARRAL, EDGAR M. CARVALHO, \\ CÉSAR C. CUBA, ALBINO V. MAGALHÃES, AND VANIZE O. MACÊDO \\ Núcleo de Medicina Tropical, Universidade de Brasília, Brasilia, Brazil; Serviço de Imunologia, \\ Hospital Universitário Professor Edgar Santos, Salvador, Bahia, Brazil
}

\begin{abstract}
We report the long-term clinical follow-up of two patients with unresponsive mucosal leishmaniasis due to Leishmania (Viannia) braziliensis from the Três Braços area in Bahia State, Brazil. Both were agricultural male workers with extensive upper respiratory mucosal involvement that was not cured with conventional and experimental therapy.
\end{abstract}

In 1985, we reported two male patients with unresponsive mucosal leishmaniasis who appeared to respond to continuous antimony therapy. ${ }^{1}$ At that time, we did not realize how long follow-up was necessary to pronounce clinical cure and both patients subsequently relapsed. In 1986, we reported a recurrence in one of these patients. ${ }^{2}$ We now report their long-term follow-up to the end of 1996. Given that a parasitologic cure is difficult to prove and may never occur in some forms of leishmaniasis, ${ }^{3}$ response to treatment and relapse were established based on clinical criteria of granuloma activity followed by confirmatory biopsy. All parasite isolations identified by monoclonal antibodies and isoenzyme taxonomy have been Leishmania (Viannia) braziliensis. The last clinical evaluation 1996 showed active mucosal granulomata despite all available treatment. This is the justification for the title of this paper. One of us (PDM) had followed these patients for 18 years. Despite recurrences after treatment, recent granulomata seem less aggressive. Both patients do not have any associated disease or condition such as tuberculosis, schistosomiasis, or blastomycosis, that can explain their peculiar evolution, which we have seen complicating recovery from $L$. (V.) braziliensis infection in humans. These patients lead normal lives and have growing families. They have spent long periods as hospital inpatients and are not anxious to re-enter the hospital. A brief update of their case histories is given with a tabulated summary of treatment regimens.

\section{CASE REPORTS}

Patient MB (LTB12), a 42-year old man, developed mucosal granulomata at the age of 20 . He had no history or sign of a cutaneous lesion. The nose, both palates, and the larynx were affected. Leishmania (Viannia) braziliensis was isolated from a nasal mucosal lesion and characterized by isoenzymes and monoclonal antibodies in 1984 and has been reisolated seven times during the last 20 years. He always responded well to antimony therapy only to relapse. After our last report, he relapsed two years later and subsequent treatment is detailed in Table 1. In our previous report, he appeared to have responded to 85 days of therapy with sodium stibogluconate (Pentostam ${ }^{\circledR}$; Wellcome, London, United Kingdom) (20 mg/kg/day) in the hospital to the tolerance limit. ${ }^{1}$ In 1996, he had active granulomata around the nasal septal perfuration confirmed by histology. He also had gran-

*Deceased. uloma on the right inferior turbinate and a immunofluorescent antibody titer of 1:80. In our laboratory, a titer $>1: 20$ is regarded as significant. Mucosal surfaces affected over time include the nasal septum, inferior turbinates, hard and soft palates, oropharynx, epiglottis, arytenoid cartilages, vocal cords, and the trachea. Many side effects have accompanied his various treatments. He showed cardiac, renal, and hepatic side effects before treatment with Pentostam ${ }^{\circledR}$ was stopped. After pentamidine therapy, he developed diabetes mellitus and cataracts that have been surgically removed. Immunologic investigations revealed no abnormality. He has always had a strongly positive leishmanin skin test result confirmed by lymphocyte transformation. No abnormality of macrophage function can be detected and lymphocyte production seems normal as previously reported..$^{1,4}$

Patient JSS (LTB 300), a 27-year-old man, had four initial skin ulcers on his right arm and leg at the age of seven. He had irregular antimonial treatment and the ulcers healed with characteristic scarring. The largest scar on the right knee was $2.6 \times 2.0 \mathrm{~cm}$. Six months after healing of this skin, mucosal involvement was noted by nasal obstruction and epistaxis. This has persisted for 20 years. His longest remission was after our initial report and he remained well from 1984 to 1990. ${ }^{1}$ Subsequent treatment is listed in Table 2. The lesions improved only to relapse. Leishmania (Viannia) braziliensis has been recently isolated from a nasal mucosal lesion and the immunofluorescent antibody titer remains positive (1: 40). Sequelae of his prolonged multimucosal surface granulomata are uvular destruction and perforation of the posterior surface of the oropharynx with visualization of the anterior surface of the cervical vertebrae, epiglottal fibrosis, and laryngeal scarring. He has a permanently hoarse voice. Due to eustachian tube blockage, he also developed chronic middle ear infection, which has been reported. ${ }^{5}$ Similar to the first patient, he shows an exaggerated delayed hypersensitivity to leishmanin both on a skin test and in lymphocytes studies and has no detectable defect of immune function.

\section{DISCUSSION}

This is an update of a clinical report regarding two unusual patients with mucosal leishmaniasis. When observed, we found a high incidence of subjects with mucosal disease since they tend to live in isolated communities with little medical care. The two patients come from families of subsistence farmers in the cacao plantations of the littoral forest of Bahia State. ${ }^{6}$ Leishmaniasis is well known among these 
TABLE 1

Drugs used by patient LTB12*

\begin{tabular}{|c|c|c|c|c|}
\hline Drug & Dosage & Duration & Place & Year \\
\hline Glucantime (irregular) & $8 \mathrm{mg}$ of $\mathrm{Sb}^{\mathrm{v}} / \mathrm{kg} / \mathrm{day}$ & NR & NR & 1976 \\
\hline Nifurtimox & $10 \mathrm{mg} / \mathrm{kg} / \mathrm{day}$ & 30 days & Field & 1978-1979 \\
\hline $\begin{array}{l}\text { Intermittent } \\
\text { Glucantime, } 3 \text { series } \\
\text { with 10-day intervals }\end{array}$ & $28 \mathrm{mg}$ of $\mathrm{Sb}^{\mathrm{v}} / \mathrm{kg} /$ day & 30 days & Field & $1978-1979$ \\
\hline Amphotericin B & $\begin{array}{l}2.5 \mathrm{~g} \text { total dose } \\
(1 \mathrm{mg} / \mathrm{kg} / \text { day })\end{array}$ & NR & Hospital & 1979 \\
\hline Pentostam & $20 \mathrm{mg}$ of $\mathrm{Sb}^{\mathrm{v}} / \mathrm{kg} / \mathrm{day}$ & 30 days & Field & 1981 \\
\hline Pentostam & $20 \mathrm{mg}$ of $\mathrm{Sb}^{\mathrm{v}} / \mathrm{kg} / \mathrm{day}$ & 85 days & Hospital & 1983 \\
\hline Glucantime plus & $10 \mathrm{mg}$ of $\mathrm{Sb}^{\mathrm{v}} / \mathrm{kg} / \mathrm{day}$ & 60 days & Field & 1987 \\
\hline Allopurinol & $15 \mathrm{mg} / \mathrm{kg} / \mathrm{day}$ & 30 days & Field & 1987 \\
\hline Pentamidine isethionate & $4 \mathrm{mg} / \mathrm{kg} /$ day $/$ three times a week & 6 weeks & Hospital & 1987 \\
\hline Glucantime & $40 \mathrm{mg}$ of $\mathrm{Sb}^{\mathrm{v}} / \mathrm{kg} / \mathrm{day}$ & 25 days & Hospital & 1991 \\
\hline Aminosidine sulfate & $\begin{array}{l}500 \mathrm{mg} \text { every } 12 \mathrm{hr} \\
\text { (16 mg/kg/day, salt) }\end{array}$ & 20 days & Field & 1991 \\
\hline Aminosidine sulfate & $\begin{array}{l}500 \mathrm{mg} \text { every } 12 \mathrm{hr} \\
(16 \mathrm{mg} / \mathrm{kg} / \mathrm{day}, \mathrm{salt})\end{array}$ & 20 days & Hospital & 1993 \\
\hline
\end{tabular}

$* \mathrm{Sb}^{v}=$ pentavalent antimony; $\mathrm{NR}=$ not recorded; Field indicates supervised daily treatment in our field clinic.

people and meglumine antimonate (Glucantime ${ }^{\circledR}$; Rhodia, Sao Paulo, Brazil) is widely used for treatment. It is bought at local pharmacies and used at a minimal dose of one ampule (425 mg of pentavalent antimony) a day given intramuscularly for 10 days. Both patients were treated before consulting us. Such low-dose treatment may promote antimony resistance in the parasite, and subsequent treatment would certainly increase this risk. ${ }^{7}$ We have our parasite stocks cryopreserved and plan to use current technology to examine cell culture amastigotes for sensitivity to Glucantime ${ }^{\circledR}$. However, it must be remembered that since cloning one isolate of the first patient discussed here produced a different L. (V.) braziliensis genotype, parasite drug resistance could be variable over time. ${ }^{8}$ Since all pentavalent antimonials dissociate or polymerize with time, we shall use a stable, well-defined drug stored at $4^{\circ} \mathrm{C} .{ }^{9}$ Another explanation for such repeated relapse is not parasite drug resistance but a failure of the host response. Despite well-formed granulomas observed by histology throughout the observation period, the immunologic parameters we have measured may be too crude to detect a subtle immunologic defect. Local immunologic abnormalities could be responsible and tissue aggression due to poor regulation of the host defense mechanisms could have an important role, but conclusive data are required. ${ }^{10}$ However, neither explanation can account for the long periods of mucosal granuloma quiescence after maximal drug treatment before relapse. The possibility of reinfection is not likely since relapse always occurred at the same mucosal sites and no new skin lesions were noted. We have not seen skin reinfections in this area, in which transmission of $L$. (V.) braziliensis occurs almost exclusively. ${ }^{11}$ This long saga of multiple unsuccessful treatments underlines the difficulty of treating some patients with mucosal leishmaniasis.

Our field clinics recommend and supervise a daily dose of $20 \mathrm{mg}$ of pentavalent antimony $/ \mathrm{kg} /$ day for 30 days for mucosal disease. At 30 days, a detailed investigation of mucosal surfaces for evidence of the inflammatory process determines if treatment should be repeated. ${ }^{6}$ If the initial treatment fails, the best alternative is amphotericin B, which has

TABLE 2

Drugs used by patient LTB 300*

\begin{tabular}{|c|c|c|c|c|}
\hline Drug & Dosage & Duration & Place & Year \\
\hline Fuadin (trivalent antimonial) & NR & NR & NR & NR \\
\hline Glucantime (irregular) & $17 \mathrm{mg}$ of $\mathrm{Sb}^{\mathrm{v}} / \mathrm{kg} / \mathrm{day}$ & NR & NR & 1976 \\
\hline Pentostam & $20 \mathrm{mg}$ of $\mathrm{Sb}^{\mathrm{v}} / \mathrm{kg} / \mathrm{day}$ & 62 days & Hospital & 1983 \\
\hline Amphotericin B & $\begin{array}{l}950 \mathrm{mg} \text { total dose } \\
(1 \mathrm{mg} / \mathrm{kg} / \text { day })\end{array}$ & NR & Hospital & 1990 \\
\hline Glucantime plus & $20 \mathrm{mg}$ of $\mathrm{Sb}^{\mathrm{v}} / \mathrm{kg} / \mathrm{day}$ & 21 days & Hospital & 1990 \\
\hline Prednisone & $40 \mathrm{mg} /$ day & 21 days & & \\
\hline Glucantime plus & $20 \mathrm{mg}$ of $\mathrm{Sb}^{\mathrm{v}} / \mathrm{kg} / \mathrm{day}$ & 40 days & Hospital & 1992 \\
\hline$\gamma$-interferon & $40 \times 10^{6}$ units & 38 days & & \\
\hline Pentamidine isethionate & $\begin{array}{l}4 \mathrm{mg} / \mathrm{kg} / \text { dose every } 2 \\
\text { days }(8 \text { doses })\end{array}$ & 13 days & Hospital & 1993 \\
\hline Aminosidine sulfate & $\begin{array}{l}500 \mathrm{mg} / 12 \mathrm{hr} \\
(16 \mathrm{mg} / \mathrm{kg} / \mathrm{day}, \text { salt })\end{array}$ & 4 series of 20 days & Hospital & 1993-1994 \\
\hline $\begin{array}{l}\text { Glucantime plus } \\
\text { radiotherapy }\end{array}$ & $20 \mathrm{mg}$ of $\mathrm{Sb}^{\mathrm{v}} / \mathrm{kg} / \mathrm{day}$ & 20 days & Hospital & 1994 \\
\hline Glucantime plus & $20 \mathrm{mg}$ of $\mathrm{Sb}^{\mathrm{v}} / \mathrm{kg} / \mathrm{day}$ & 3 series of 20 days & Hospital & 1995-1996 \\
\hline Pentoxyphylline & $400 \mathrm{mg}$ three times a day & 3 series of 40 days & & \\
\hline
\end{tabular}

* For definitions and abbreviations, see Table 1. 
shown good results in nearly all patients. Rare patients, such as the two in this study, are candidates for experimental therapy with pentamidine, aminosidine sulfate, or combinations such as Glucantime ${ }^{\circledR}$ plus pentoxifylline (Tables 1 and 2). In our present state of knowledge, follow-up examinations are recommended at six-month intervals indefinitely.

Acknowledgment: We thank Ednaldo Lago (Ministry of Health of Brazil) for outstanding work during the follow-up period.

Authors' addresses: Hélio A. Lessa, Jaqueline G. Marotti, Aldina Barral and Edgar M. de Carvalho, Serviço de Imunologia, Hospital Universitário de Salvador, Professor Edgar Santos (HUPES), João das Botas, S/N Salvador, Bahia, Brazil. Maria R. F. Oliveira, Gustavo A. Sierra Romero, Raimunda N. R Sampaio, César C. Cuba, Albino V. Magalhães and Vanize O. Macêdo, Núcleo de Medicina Tropical, Universidade de Brasília, Campus Universitário, Asa Norte, Brasília, DF, 70919-970 Brazil.

Reprint requests: Gustavo A. Sierra Romero, Núcleo de Medicina Tropical, Universidade de Brasília, Campus Universitário, Asa Norte. Brasília, DF, 70919-970, Brazil.

\section{REFERENCES}

1. Marsden PD, Sampaio RN, Carvalho EM, Veiga JP, Costa JLM, Llanos-Cuentas EA, 1985. High continuous antimony therapy in two patients with unresponsive mucosal leishmaniasis. Am J Trop Med Hyg 34: 710-713.
2. Marsden PD, Netto EM, Badaró R, Cuba CAC, Costa JML, Barreto AC, 1986. Letter Am J Trop Med Hyg 35: 449.

3. Guevara P, Ramírez JL, Rojas E, Scorza JV, González N, Anez $\mathrm{N}, 1993$. PCR detection of Leishmania braziliensis in blood samples 30 years after spontaneous cure. Lancet 341: 1341.

4. Carvalho EM, Johnson WD, Barreto E, Marsden PD, Costa JML, Reed S, Rocha H, 1985. Cell mediated immunity in American cutaneous and mucosal leishmaniasis. J Immunol 135: 4144-4148.

5. Lessa HA, Carvalho EM, Marsden PD, 1994. Eustachian tube blockage with consequent middle ear infection in mucosal leishmaniasis. Rev Soc Bras Med Trop 27: 103.

6. Marsden PD, 1986. Mucosal leishmaniasis (Espundia Escomel 1911). Trans $R$ Soc Trop Med Hyg 80: 859-876.

7. Grogl M, Thomasin TN, Franke ED, 1992. Drug resistance in leishmaniasis: its implications in systemic chemotherapy of cutaneous and mucocutaneous disease. Am J Trop Med Hyg 47: 117-126.

8. Cuba-Cuba CA, Evans D, Rosa AG, Marsden PD, 1991. Clonal variation within a mucosal isolate derived from a patient with Leishmania (Viannia) braziliensis infection. Rev Inst Med Trop São Paulo 33: 343-350.

9. Romero GAS, Oliveira MRF, Correia D, Marsden PD, 1996 Características físico-químicas do antimoniato de meglumina em diferentes condições de armazenamento. Rev Soc Bras Med Trop 29: 461-465.

10. Pirmez C, Yamamura M, Uyemura K, Paes-Oliveira M, Conceição-Silva F, Modlin L, 1993. Cytokine patterns in American cutaneous leishmaniasis. J Clin Invest 91: 1390-1395.

11. Rosa AC, Cuba CC, Vexenat A, Barreto AC, Marsden PD, 1988. Predominance of Leishmania braziliensis in the regions of Três Braços and Corte de Pedra, Bahia, Brazil. Trans $R$ Soc Trop Med Hyg 82: 409-410. 